\title{
How the Timing of Children Affects Earnings in 20 Occupations
}

Liana Christin Landivar

Sociologist and Senior Researcher

Maryland Population Research Center

liana.c.landivar@gmail.com

\begin{abstract}
Ample evidence shows that mothers earn less than non-mothers, yet recent studies show that the motherhood earnings penalty diverges by occupation. Women in professional occupations have greater access to workplace benefits which help reconcile work-family responsibilities and reduce non-employment spells. However, because of their higher earnings, women in professional occupations who re-enter after a break may experience significant earnings penalties. One strategy women employ to mitigate the earnings penalty is to delay childbearing. Here, I examine whether delayed fertility is positively associated with a reduced motherhood wage gap across 20 occupations. Using multilevel models and 2011-2015 American Community Survey data, I show that mothers in professional occupations experienced the largest earnings penalty with early motherhood, but also the largest premium with delayed childbearing. While delaying a first birth mitigates the earnings penalty in high-wage occupations requiring extensive career preparation, women in low-wage occupations experienced little economic benefit from older motherhood.
\end{abstract}

Key words: occupations; motherhood wage gap; fertility

Presented at the Association for Public Policy Analysis and Management conference, November 3, 2017, Chicago, IL.

Draft under revision 


\section{How the Timing of Children Affects Earnings in 20 Occupations}

\section{Introduction}

Motherhood is costly. Ample evidence shows that employed mothers earn less than their childless peers (Waldfogel 1998; Budig and England 2001; Correll, Benard, and Paik 2007), and this earnings gap is commonly referred to as the "motherhood penalty" (Gough and Noonan 2013). Yet, not all mothers experience an earnings penalty. The presence and magnitude of the earnings penalty varies based on women's demographic and economic characteristics, as well as the characteristics of the occupation they work in. A related literature shows that the motherhood earnings penalty also varies based on the timing of children, as women who delay their first birth accumulate more human capital (Blackburn, Bloom, and Neumark 1993; Taniguchi 1999; Miller 2011). Women who delay childbearing also have longer work tenure resulting in greater access to employer flexibility and benefits (Laughlin 2011; Amuedo-Dorantes and Kimmel 2005), which can reduce work-family conflict and increase job attachment resulting in improved earnings prospects (Waldfogel 1998; Kossek and Distelberg 2009). However, not all women are employed in occupations that reward human capital accumulation or that provide workplace flexibility and benefits. Therefore, delayed childbearing may only be effective at increasing earnings among women working in, or transitioning to, select occupations that reward higher levels of human capital and offer workplace benefits.

Here, I examine how occupational characteristics and the timing of children jointly affect mothers' earnings in 20 diverse occupations. I ask three questions: (1) how variable is the motherhood earnings penalty across occupations?, (2) does a delayed first birth reduce the motherhood earnings penalty in all occupations?, and (3) how do occupational characteristics interact with first-birth timing to enhance or mitigate the motherhood earnings penalty? This study contributes to the existing literature on the motherhood wage gap in several ways. First, I 
expand upon recent research that shows that mothers in professional occupations experience the largest earnings penalty (England et al. 2016) by disaggregating the motherhood earnings penalty by age and timing of first birth. I show that mothers in professional occupations experience the largest earnings penalty if they have children before age 25, but have the largest earnings premium if they have their first child after age 28. Second, I model the effect of birth timing within occupations directly. Using multilevel models, I allow the effect of birth timing to vary across occupations rather than assuming a single, fixed effect of birth timing in all occupations. This modeling strategy shows that the effect of delayed childbearing ranges from a 19 percent earnings penalty to a 21 percent earnings premium depending on the mother's occupation. Crucially, this study shows that while delaying fertility helps mitigate the motherhood earnings penalty among women in occupations requiring extensive preparation for career advancement, women in low-wage occupations with limited vocational preparation requirements experienced little economic benefit from older motherhood. Therefore, fertility delay as a mechanism to mitigate the motherhood earnings penalty is effective for only a minority of women.

Data for this research come from the 2011-2015 American Community Survey Public Use Microdata Sample (ACS). As the largest household survey in the United States, the ACS is ideal for the evaluation of occupation effects which require large samples to do so effectively. By combining five years of the ACS, the sample is robust for measuring the timing of first birth within occupations. Supplementary data come from the O*NET database of occupational characteristics and the Occupational Outlook Handbook developed by the U.S. Department of Labor, as well as the 2004 Work Schedules Supplement of the Current Population Survey. Using these data, I show that there is significant variability in the motherhood wage gap by occupation and that the effect of first-birth timing varies by occupation and occupational characteristics. 


\section{The Motherhood Earnings Penalty and the Timing of Children}

Who Experiences the Largest Penalty? The 'Price of Privilege' Examined

The motherhood earnings penalty is well documented. Even as mothers have increased their labor force participation over time, researchers consistently find that mothers earn less than non-mothers. Compared with non-mothers, estimates of the motherhood earnings penalty range from 6 to 7 percent for mothers of one child to 12 to 13 percent for mothers of multiple children (Anderson, Binder, and Krause 2003; Amuedo-Dorantes and Kimmel 2005). However, not all mothers experience an earnings penalty, and there is disagreement among researchers on who experiences the largest penalties. On one hand, researchers show that highly educated women in professional occupations experience lower earnings penalties than other mothers. For instance, Anderson, Binder, and Krause (2003) find no wage penalty among the least and most educated. Budig and England (2001) find a lower wage penalty among women in managerial and professional jobs. Amuedo-Dorantes and Kimmel (2005) show that college-educated women do not experience an earnings penalty, rather a wage premium associated with delayed childbearing.

On the other hand, other research shows that the most highly skilled and paid mothers experience the steepest earnings penalties because of their higher returns to experience (Wilde, Batchelder, and Ellwood 2010; England et al. 2016).

Women at the top of the earnings distribution are privileged in many ways. Women in these professional occupations, not only enjoy higher wages, but they are more likely to have access to paid leave and retirement benefits (Bureau of Labor Statistics 2017a; Bureau of Labor Statistics 2017b). Although work-hour expectations are higher in these jobs, women are more likely to have the flexibility to adjust their schedules to meet work and family demands (Landivar 2014). Nevertheless, higher returns to experience result in a higher wage penalty 
among highly skilled, highly paid women, which England and her colleagues (2016) refer to as the price of privilege. Although advantaged in earnings and benefits, among the few women who do temporarily leave the labor force, the earnings penalty is steep. Evaluating the earnings gap among lawyers, Noonan, Corcoran, and Courant (2003) similarly show that even several months to a year spent in a non-work or part-time work status yields a significant earnings penalty. Lawyers who worked part time for a year were estimated to have a 4.8 percent reduction in earnings, while those who left the labor force for a year experienced an 8.4 percent earnings penalty. Although women in professional occupations are the least likely to leave the labor force (Landivar 2017), England and her colleagues (2016) find that the steep earnings penalty associated with temporary exits makes up for their reduced spells of non-employment.

Occupational characteristics play a key role in determining women's employment continuity following birth, as well as the size of the cumulative motherhood earnings penalty. Occupational characteristics can shape the work environment and expectations and create conditions that are more or less hospitable to parents. Yet few studies examine how structural characteristics of occupations affect mothers' earnings (Yu and Kuo 2017). Goldin (2014) finds that occupations that value long work hours and job continuity have a higher gender wage gap. Occupations that place a premium on hours worked and client relationships (lawyers, for example), are more disadvantageous for workers with family responsibilities than flexible occupations with work interchangeability (pharmacists, for example). Yu and Kuo (2017), evaluating occupational characteristics that impact the motherhood earnings gap, find that mothers who have more autonomy and are in jobs requiring less teamwork experience lower earnings penalties. These characteristics moderate the wage gap by easing work-family conflict. Yet, similar to the price of privilege, Schieman, Milkie, and Glavin (2009) argue that privileged 
workers - those who are highly-paid and have autonomy and schedule flexibility -experience greater work-to-family spillover because of higher job demands, which they identify as the stress of higher status. Schedule control and autonomy may not shield them from work-family role stress because of the jobs' more intense pressure. Among women, these pressures have been linked with labor force exit and reduced lifetime earnings (Epstein et al. 1999; Stone 2007). Reconciling Mixed Findings on the Motherhood Wage Gap

Collectively, the motherhood wage gap literature presents seemingly conflicting findings. While some researchers find greater penalties among highly-skilled, high-earner workers (Wilde, Batchelder, and Ellwood 2010; England et al. 2016), other researchers find lower penalties or an earnings premium among high-earning, professional workers (Budig and England 2001; Amuedo-Dorantes and Kimmel 2005; Landivar 2017). This highlights the complexity of the earnings gap and the need to delve deeply to explore this variability. To reconcile these prior findings on the motherhood earnings penalty, this study evaluates the motherhood earnings penalty in 20 occupations and expands the analyses to include first-birth timing.

Delayed childbearing is one strategy women use to mitigate career and earnings penalties and reduce work-family conflict. Women in professional occupations are especially likely to delay having children, which may allow them to establish a career and obtain access to more employment benefits. These benefits, in turn, may enable them to remain employed or return to the same employer following the birth of a child (Boushey 2008; Waldfogel 1998). Research shows that delayed first births are associated with increased earnings. Women who had their first child after age 30 earned 6 percent more than childless women, and 13 percent more if they were college-educated (Amuedo-Dorantes and Kimmel 2005). Delayed childbearing results in higher wages through greater investments in human capital (Blackburn, Bloom, and Neumark 1993), 
higher returns to education (Blackburn, Bloom, and Neumark 1993), and more continuous work experience (Taniguchi 1999; Aughinbaugh and Sun 2016).

Considering the motherhood earnings penalty across 20 occupations, I expect that the motherhood earnings penalty will vary considerably by occupation, while first-birth timing will only be significant in high-earning professional occupations. Specifically, mothers in highearning professional occupations are expected to have the largest earnings penalty if they have children at a young age through reduced or foregone human capital accumulation. In contrast, women in occupations with limited workplace benefits and educational requirements are expected to receive no financial returns to fertility delay. Having children at older ages may be a viable strategy to boost earnings among women who would pursue higher education and are in a job that rewards investments in human capital, affording a ladder to climb. In jobs that do not offer paths for promotion, do not reward tenure or career networks, nor make use of investments in higher education, it is not clear if or how delayed childbearing would matter. I explore these issues here, examining whether the gains to delayed childbearing affect women equally or if they diverge by occupation. First, I show how the unadjusted motherhood earnings penalty differs by occupation. Next, I evaluate how occupational characteristics that represent human capital requirements (i.e., vocational and educational preparation, licensing) and reduce work-family conflict (i.e., job autonomy and schedule flexibility) affect the motherhood earnings gap. Finally, I show the adjusted, occupation-specific effect of delayed fertility across 20 occupations.

\section{Analytic Strategy}

Data and Methods

Data for these analyses come from the 2011-2015 American Community Survey Public Use Microdata Sample provided by the Integrated Public Use Microdata Series (IPUMS) 
(Ruggles et al. 2015). The total sample size is 457,907 women. The sample is restricted to women between the ages of 35 and 50 who are currently employed in 20 selected occupations (descriptive statistics are provided in Table 1). Age is restricted to 35 and older to capture women who have completed higher education and career preparation. Initial models included younger women, but this posed a problem for comparisons in some occupations that had extraordinarily long educational preparation or career apprenticeship periods. For example, younger physicians are typically medical residents or fellows (and correctly coded as physicians and surgeons per the Standard Occupational Classification system), and they have wages that are lower than physicians who have completed their residency. At the same time, medical residents are less likely to have children. Thus, the unadjusted wage gap between young mothers and nonmothers was implausibly large (mothers were earning two to three times more than non-mothers) because childless residents were compared with slightly older physicians who had entered into motherhood. Nevertheless, earlier research that included women aged 18 to 50 showed similar occupational patterns in the association between earnings and birth timing (Landivar 2017). Because this earlier study used occupational groups (e.g., healthcare practitioners or legal occupations) rather than individual occupations (e.g., physicians and lawyers), unadjusted earnings differences within narrow age bands due to long vocational preparation were less pronounced. At the other end of the distribution, age is restricted to 50 to include a control variable for having a birth in the past 12 months, a question only asked of women aged 50 and younger.

Women are classified as having delayed first births if their first birth occurred at age 28 or older. Women are classified as having early first births if the birth occurred before age 25 . Normative first birth timing ranged from ages 25 to 27 . The mean age of first-time mothers in 
2014 was 26.3 (Mathews and Hamilton 2016), and prior research uses age 28 as a cutoff for delayed childbearing (Taniguchi 1999). I also tested an alternative specification of fertility delay, using occupation-specific age cutoffs based on the normative fertility timing in that occupation. Most results were not meaningfully different, therefore I retained a single, consistent definition of fertility timing across the pooled sample. I focus on the timing of the first birth, as this marks the transition into parenthood. Research shows that the timing of the first birth leads to the most significant adjustments in labor force participation, with most women making a determination following the first birth whether to work continuously, withdraw, or work part time (Yao, Wang, and Han 2017). One limitation to using ACS is that the ACS provides data on resident children, thus this source will not account for children who live elsewhere.

Yu and Kuo (2017) use O*NET and the 1997 National Longitudinal Survey of Youth to determine how occupational characteristics affect mothers' earnings and the wage gap. Two key limitations to their study are the sample size and age of their sample. With about 4,200 respondents, most of whom are under the age of 35, they do not have the sample to look at the wage gap within each occupation or to evaluate how the timing of births impacts earnings at older ages. As I show in this study, capturing women's earnings after age 35 is important in the highest-paying occupations. Rather than measuring occupations directly, Yu and Kuo (2017) use occupation to create an index of occupational characteristics, thus measuring some attributes of occupations, but not occupations themselves. In addition to measuring occupational characteristics that represent job autonomy, vocational and educational requirements, and licensing requirements, this study measures occupation directly. As I show in Table 2, occupations provide a wide array of attribute "packages." Occupations with a high degree of autonomy do not always require extensive vocational preparation or long work hours (e.g., 
housekeeping cleaners), and some occupations with extensive vocational preparation may not come with autonomy (e.g., elementary and middle school teachers). Nearly every occupation has a different combination of attributes, each of which contributes to a higher or lower earnings gap.

The 20 occupations selected for this study are diverse and employ about half of working women. I exclude the self-employed, as the 20 occupations selected are not representative of self-employed individuals and within some occupation categories, may lead to biased earnings estimates. Many of the occupations selected are among the largest employing working women, and each occupation is large enough to estimate the effect of timing of first births with precision. The occupations selected also allow for insightful pairings within industry (e.g., lawyers and paralegals; elementary and middle school teachers, teacher assistants, and childcare workers). Initial OLS regression models estimate the effect of selected occupation attributes while excluding occupation. Subsequently, I model the occupation-specific effect of birth timing in 20 occupations using multilevel models. Multilevel models are useful when data are nested within groups (here, individuals are nested within occupations) as they do not require the assumption of independence between observations. Furthermore, rather than estimating fixed effects for early and delayed childbearing across occupations, I allow the effects to vary by occupation. For example, while the overall effect of a delayed first birth is to raise earnings by 3 percent, the effect is much larger among lawyers (16 percent) than among paralegals (no effect). Multilevel models allow us to derive these random effects (Snijders 2005). Individual characteristics, with the exception of the timing of first births, are grand mean centered to allow for easier interpretation of the coefficients.

ACS data are cross-sectional. As such, work history information is largely unavailable. Work history data are typically restricted to small-scale longitudinal surveys that do not have a 
large enough sample to evaluate occupation with precision. Instead, estimates presented are highly unreliable or rely on major occupational groupings. Large occupation groups, such as the commonly used "managerial and professional" category, obscure important differences in earnings, benefits, and work patterns. Classified within managerial and professional occupations, for example, are paralegals and lawyers, teachers and teaching assistants. These occupations offer drastically different earnings and benefits and pose different educational and work requirements, thus they ought to be considered separately. These higher-level groupings are especially inadequate to examine the motherhood earnings gap because, as I will show, earnings penalties and premiums diverge sharply within these larger occupational groupings. To overcome limitations stemming from the use of cross-sectional data, I compare the natural log of earnings among employed women who are of the same age and working in the same occupation. I control for numerous demographic and economic characteristics that might differentiate these two groups of women. As an additional check, I control for having a birth in the last 12 months. Several studies show that women's earnings trajectories typically diverge after a birth, not preceding it (Wilde, Batchelder, and Ellwood 2010), and the relationship between having children and women's earnings is causal (England et al. 2016). Furthermore, in prior research I show that occupational switching following a birth is minimal, especially switching into managerial and professional occupations (Landivar 2017).

Measures

\section{Dependent Variable}

The dependent variable is the natural logarithm of earnings. Earnings capture the sum of wage and salary income, including bonuses and tips, earned during the 12 months prior to the interview. In descriptive statistics, the earnings gap is the unadjusted difference between the 
earnings of mothers and non-mothers in the same age group. In modeled estimates, the earnings gap is the adjusted difference between mothers' and non-mothers' earnings.

\section{Independent Variables}

The OLS models estimate how occupational characteristics affect earnings, while controlling for an individual's demographic characteristics. These include age, timing of first birth (early $=24$ or younger, normative $=25-27$, and delayed $=28$ or later; women without children are the reference category), birth in the past 12 months, marital status (1= married), race (non-Hispanic White, Black, Asian, and other), and ethnicity (1=Hispanic). Other economic and human capital variables are also included, such as educational attainment (some college and college degree or higher), school enrollment (1=enrolled), weeks worked (categorical variable with 50-52 weeks as the reference category), hours worked, and the natural logarithm of family income (respondent income subtracted). Age squared was not significant so it was dropped.

The key predictors in the OLS models are the occupational characteristics. Autonomy is an index that captures the extent to which employees have freedom to make decisions, freedom to structure and prioritize their tasks and goals, and set their work schedules. These measures are strongly correlated (alpha $=.73)$ and could not be entered into the model separately with acceptable levels of collinearity. This measure is similar to the measure Yu and Kuo (2017) construct. This study and theirs both use freedom to make decisions and to prioritize tasks and goals, obtained from the $\mathrm{O} *$ NET database of occupational characteristics developed by the Department of Labor. Yu and Kuo include a third measure that captures frequency of decisionmaking, whereas I include schedule flexibility. Schedule flexibility, or the ability to choose the start and end times of one's work schedule, is obtained from the 2004 Work Schedules 
Supplement of the Current Population Survey. Being able to control one's schedule is an important type of autonomy, and especially relevant to the management of work-family conflict.

In addition to autonomy, I include measures for specific vocational preparation and licensing. The specific vocational preparation (SVP) required in an occupation is obtained from $\mathrm{O} * \mathrm{NET}$, and is defined as the amount of time required by a typical worker to learn the techniques and information to perform at an adequate level in an occupation. SVP ranges from 1 to 9 , where 1 is "short demonstration only" and 9 is "over 10 years." Whether an individual requires a license or certification to be employed in an occupation is obtained from the Occupational Outlook Handbook. These measures combined will show how required occupational preparation affects the earnings premium of delayed childbearing.

Multilevel models include all individual characteristics, but exclude occupational characteristics to model occupation directly. The 20 occupations selected are presented in Table 2. Occupations are classified in accordance with the Standard Occupational Classification 2010. These occupations were selected because they employ a large number of workers, are diverse in occupational characteristics, and represent high- and low-income employment.

\section{Results}

Who Earns More

Comparing mothers and non-mothers in two different age groups (35-39 and 45-50), lawyers had the largest unadjusted earnings penalty for early childbearing, as well as the largest unadjusted earnings premium for delayed childbearing (Figure 1). Physicians and surgeons and managers exhibited similar patterns of large earnings penalties for early childbearing and premiums for delayed childbearing. Workers in most other occupations only saw a modest gain from delayed childbearing. By ages 45 to 50, few occupations showed any gains to delayed 
childbearing or penalties for early childbearing other than physicians and surgeons, lawyers, managers, and software developers.

When examining the earnings gap as a percent, patterns remained consistent with lawyers maintaining the largest persistent earnings penalty among early childbearers along with the largest premium for delayed first births (figure available upon request). The earnings gap between mothers and non-mothers becomes more pronounced in lower-earning occupations when evaluated as a percentage. However, by ages 45 to 50, most low-income occupations do not have a statistically significant earnings gap, while the gap remains large among physicians and surgeons, lawyers, managers, and software developers whether presented in dollars or percent. Younger mothers (ages 35-39) in low-income occupations earn less than non-mothers whether they had early or delayed births, with the exception of retail salespersons. This provides preliminary evidence that timing of first births has a weaker association with earnings in lowincome occupations. To determine whether demographic or occupational characteristics help explain these patterns, I use OLS regression and multilevel models and turn to these next.

\section{Occupational Characteristics}

Higher job autonomy, longer specific vocational preparation (SVP), and licensing requirements are all associated with increased earnings among women (Table 3). Autonomy is associated with a 2 percent increase in earnings per percent increase in job autonomy, and SVP is associated with earning 5 percent more per increase in SVP rating. Working in an occupation that requires licensing is associated with 26 percent higher pay. Because of the difference in metrics, the magnitude of the effect should be compared accordingly. Job autonomy ranges from $0-100$, so a percent increase in earnings is associated with a 1 percent change in autonomy. Licensing is a binary measure (0-1), so a percent change in earnings is associated with being in a 
licensed occupation. SVP ranges from 0-9, so a percent change in earnings is associated with moving 1 step on SVP.

When considering interaction effects between occupational characteristics and the timing of first birth, these occupational characteristics have a different effect on mothers, based on the timing of their children. Having job autonomy and being in an occupation that requires licensing had consistently positive earnings effects (Figure 2). Job autonomy increased earnings by an additional 1 percent among mothers with delayed childbearing, but had no additional positive effect among women with normative or early childbearing. Similarly, licensing increased earnings by 4 percent among women with delayed first births, but was not significant among women with earlier childbearing. While licensing could theoretically act as a barrier to employment if mothers take time off following the birth of a child and do not renew or maintain a required license, this effect is not observed here. This could, in part, stem from the types of jobs that require licensing. Two of the largest occupations among employed women are teachers and registered nurses, both of which require licensing. Employment continuity among mothers in both of these occupations is relatively high (Landivar 2017).

Specific vocational preparation had mixed effects: while women with delayed childbearing earned 3 percent more in higher SVP occupations, women with early first births earned 4 percent less. Because SVP is positive for women who delay their first birth and negative for early childbearers, this is consistent with human capital accumulation theories. That is, women who delay childbearing are more likely to invest in higher educational attainment and career preparation (Blackburn, Bloom, and Neumark 1993). Research also shows that women who had children at a younger age face higher earnings penalties for career disruptions in occupations that require higher levels of educational attainment (Herr 2016). However, the 
penalty for earlier childbearing in high SVP occupations could also be capturing lost work experience which may be more significantly penalized in high SVP occupations.

After accounting for all occupational characteristics jointly, there is no premium for delayed childbearing (Table 3, model 5). This provides some support for the mechanism of fertility delay operating through increased educational preparation and improved job conditions that mitigate work-family conflict. Especially significant is job autonomy. Delayed childbearing is no longer significant after accounting for the level of job autonomy in an occupation.

However, the relationship between all occupational characteristics is important, and only fully captured by measuring occupation directly. As Schieman, Milkie, and Glavin (2009) find, higher autonomy is strongly correlated with long average work hours in an occupation $\left(\mathrm{r}=.75^{* * *}\right)$. Autonomy is also correlated with specific vocational preparation $\left(\mathrm{r}=.65^{* * *}\right)$. On the other hand, the correlation between autonomy and licensing is weak and the correlation coefficient is negative $\left(-.13^{* * *}\right)$. While autonomy is typically present in high-earning occupations that require long hours of work, higher levels of autonomy are also present in lower-paying occupations such as housekeeping. Similarly, licensing covers a wide range of occupations. These include lowearning occupations such as nursing and home health aides, along with high-earning occupations such as lawyers and physicians. Each occupation comes with a unique set of attributes (Table 2), and some of these attributes may provide mixed effects on earnings. For instance, teachers have higher levels of SVP, but low autonomy. Without examining occupation directly, occupational characteristics may act as an incomplete proxy for occupation.

\section{Occupation Effects}

Turning to the multilevel models to evaluate the effect of occupation, we see that after controlling for occupation directly, birth timing remains important (Table 4). Women with 
delayed childbearing do not have an earnings penalty, but women with normative or early first birth timing earn between 3 and 4 percent less than non-mothers. Figure 3 shows the occupationspecific effects of delayed first birth timing. These are derived from multilevel models that treat birth timing as a random effect across occupations, and presented in Table 5 which is a continuation of the model presented in Table 4 . The association between birth timing and earnings varied substantially by occupation. Furthermore, delayed first births did not reduce the earnings penalty for mothers in all occupations. Delayed first births provided the greatest returns to mothers in high-earning occupations with substantial educational and career preparation requirements. These include, physicians and surgeons, lawyers, and managers. Physicians earned 21 percent more than non-mothers if they delayed having children until age 28 or later. Lawyers earned 16 percent more and managers earned 8 percent more with delayed childbearing.

Mothers in most occupations (12 out of 20) experienced no earnings premium following a delayed first birth, where earnings were not statistically different from non-mothers. However, delayed parenthood mitigated experiencing an earnings penalty for accountants and teachers. In lower-earning occupations, mothers experienced either no effect from delaying a first birth or experienced an earnings penalty. Occupations with the largest earnings penalties for delayed first births include child care workers and teacher assistants, each earning between 19 percent and 14 percent less if they had a first birth at age 28 or older. Secretaries, retail salespersons, and bookkeepers also experienced a statistically significant earnings penalty (Figure 3). The earnings premium associated with delayed childbearing is correlated with women's share of the contribution to household income $\left(\mathrm{r}=.67^{* * *}\right)$. That is, the earnings premium to fertility delay is higher among women who contribute a larger share of the household income. Child care workers and teacher assistants, both low-earning occupations with the largest penalties for delayed first 
births, contributed the least to household income (about one third). In some lower-earning occupations, mothers actually experienced an earnings premium with early childbearing. These include housekeeping cleaners, nursing aides, bus drivers, and cashiers (Figure 4). These results are consistent with Herr's (2016) findings that women without a college degree earned more if they had children early and prior to labor force entry because it minimized disruption caused by labor force exit. Women in low-earning occupations are especially unlikely to have access to family leave, therefore they are more likely to quit their jobs following childbirth.

Pairing results within industry shows that the benefits to fertility delay largely accrue to women in the higher-paying professional occupations. However, mothers are penalized more significantly in some industries. Taking three groupings of occupations, paired by dominant industrial setting, we see that occupations with extensive educational requirements and job autonomy experience an earnings premium with delayed childbearing (Figure 5). Women in the same industry with less job autonomy and reduced vocational requirements do not experience similar gains to fertility delay. For example, physicians and surgeons experience an earnings premium with delayed fertility (21 percent higher earnings), whereas nursing, psychiatric, and home health aides do not (3 percent, not statistically significant). Educational and vocational requirements vary significantly within industry, and workplace benefits can vary by occupation even within the same company (Landivar 2017). High-earning, professional workers receive the highest returns on investment in human capital and are more likely to receive workplace benefits, therefore fertility delay disproportionately benefits this group of workers.

Comparing across industry, we see that mothers in education are more likely to experience an earnings penalty associated with motherhood than are mothers in healthcare. The education sector offers low levels of job autonomy and relatively lower earnings. In contrast, 
healthcare offers more autonomy and higher earnings, especially among physicians and surgeons and registered nurses. In a detailed study of work schedules in healthcare, Dan Clawson and Naomi Gerstel (2014) show that doctors and registered nurses had greater leverage to request flexible schedules and employment accommodations due to demand in their occupations. Mothers used this leverage to obtain schedules that better fit their family needs. Having this schedule flexibility allows women to maintain full-time hours after they have children (Landivar 2014), which is protective against experiencing an earnings penalty associated with motherhood. As the healthcare sector has increasingly adopted standardized recording and treatment procedures, this has reduced the need for patients to be attended by the same staff (Briscoe 2009). To the extent that workers can be substitutable, their work can be taken on by others, and often with no pay penalty. Pharmacists, for example, can substitute for each other, knowing their client's history and needs as well as any other pharmacist, and Goldin (2014) finds no pay premium to working long hours in pharmacy. The weakening of the client relationship has increased flexibility in some occupations, allowing workers more control over work timing and improved work-life fit.

\section{Conclusion}

This study contributes to our understanding of the motherhood wage gap by analyzing how the timing of children affects mothers' earnings within specific occupations. I show that the motherhood wage gap diverges significantly by occupation and is associated with first birth timing, but not always in ways we would expect. Managers, physicians and surgeons, and lawyers all experienced significant earnings penalties if they had children at a young age, but earned more than non-mothers if they had children after age 27. England and colleagues (2016) indicate that these high-earning women pay the largest earnings penalties because of their returns 
to experience. My results show that high-earning women do have higher earnings penalties, but only if they have children at a young age. Because women in these occupations are especially likely to delay fertility, women in high-earning occupations experience an earnings premium, not a penalty, on average.

Outside of high-earning professional occupations, women experienced no financial gains to delayed childbearing. In low-income occupations, delayed childbearing was associated with an earnings penalty in five occupations, and early childbearing was associated with higher earnings in four occupations. Herr (2016) offers one explanation for this unexpected finding. She shows that the timing of childbearing relative to labor force entry is important among women without a college degree. Women without a college degree had higher wages if their first birth happened prior to labor force entry because it resulted in less career disruption.

Workers with job autonomy and more career preparation have higher earnings and a lower earnings penalty relative to non-mothers. Though workers with more schedule flexibility and autonomy may experience greater job demands and other disadvantages (Schieman, Milkie, and Glavin 2009), schedule flexibility and autonomy do reduce the motherhood earnings gap for women with delayed fertility. Women who delay having children may have the opportunity to establish career networks, complete vocational preparation, and obtain formal and informal employment benefits, including flexibility and autonomy. Workers in the low-paying retail and service sectors typically do not accrue benefits and turnover is high, with limited returns to tenure. Specific vocational preparation is low, and investments in human capital may not yield returns. In many service sector jobs, workers can perform an adequate job with less than 1 month of preparation. In contrast, $\mathrm{O} * \mathrm{NET}$ indicates that all occupations requiring extensive preparation were managerial and professional. Average job tenure in management and legal occupations was 
6 years, two to three times higher than tenure among food preparation workers or sales occupations (Bureau of Labor Statistics 2016). These characteristics of low-income occupations indicate that human capital is devalued and does not yield high returns. Therefore, while delaying childbearing may be an effective strategy to mitigate the earnings penalty among the minority of women employed in occupations requiring advanced degrees for career advancement, women in low-wage occupations with limited vocational preparation requirements experienced little economic benefit from older motherhood. 


\section{References}

Amuedo-Dorantes, Catalina and Jean Kimmel. 2005. "The Motherhood Wage Gap for Women in the United States: The Importance of College and Fertility Delay." Review of Economics of the Household 3(1): 17-48.

Anderson, Deborah J., Melissa Binder, and Kate Krause. 2003. "The Motherhood Wage Penalty Revisited: Experience, Heterogeneity, Work Effort, and Work Schedule Flexibility.” Industrial and Labor Relations Review 56(2): 273-274.

Aughinbaugh, Alison and Hugette Sun. 2016. "Fertility of Women in the NLSY79." Monthly Labor Review. April.

Blackburn, McKinley L., David E. Bloom, and David Neumark. 1993. "Fertility Timing, Wages, and Human Capital." Journal of Population Economics 6(1): 1-30.

Boushey, Heather. 2008. "Family Friendly Policies: Helping Mothers Make Ends Meet." Review of Social Economy 66(1): 51-70.

Briscoe, Forrest. 2009. "The Design of Work as a Key Driver of Work-Life Flexibility for Professionals." Pp. 83-93 in Work-Life Policies, edited by Ann C. Crouter and Alan Booth. Washington, DC: Urban Institute Press.

Budig, Michelle J. and Paula England. 2001. “The Wage Penalty for Motherhood.” American Sociological Review 66(2): 204-225.

Budig, Michelle J. and Melissa Hodges. 2010. "Differences in Disadvantage: Variation in the Motherhood Penalty Across White Women's Earnings Distribution.” American Sociological Review 75(5): 705-728.

Bureau of Labor Statistics. 2016. "Median Years of Tenure With Current Employer for Employed Wage and Salary Workers by Occupation, Selected Years, 2006-2016.” Available online: https://www.bls.gov/news.release/tenure.t06.htm. Retrieved October 2, 2017. 
-----. 2017. "Selected Paid Leave Benefits: Access." Available online:

https://www.bls.gov/news.release/ebs2.t06.htm. Retrieved January 8, 2018.

----. 2017. "Retirement Benefits: Access, Participation, and Take-Up Rates." Available online: https://www.bls.gov/ncs/ebs/benefits/2017/ownership/private/table02a.htm. Retrieved January 8, 2018.

Clawson, Dan and Naomi Gerstel. 2014. Unequal Time: Gender, Class, and Family in Employment Schedules. New York: Russell Sage Foundation.

Correll, Shelley J., Stephen Benard, and In Paik. 2007. “Getting a Job: Is There a Motherhood Penalty?” American Journal of Sociology 112(5): 1297-1338.

England, Paula, Jonathan Bearak, Michelle J. Budig, and Melissa J. Hodges. 2016. "Do Highly Paid, Highly Skilled Women Experience the Largest Motherhood Penalty?" American Sociological Review 81(6): 1161-1189.

Epstein, Cynthia Fuchs, Carroll Seron, Bonnie Oglensky, and Robert Sauté. 1999. The Part-Time Paradox: Time Norms, Professional Life, Family, and Gender. New York: Routledge. Goldin, Claudia. 2014. “A Grand Gender Convergence: Its Last Chapter.” American Economic Review 104(4): 1081-1119.

Gough, Margaret and Mary Noonan. 2013. "A Review of the Motherhood Wage Penalty in the United States.” Sociology Compass 7(4): 328-342.

Herr, Jane Leber. 2016. "Measuring the Effect of the Timing of First Births on Wages." Journal of Population Economics 29(1): 39-72.

Killewald, Alexandra and Jonathan Bearak. 2014. "Is the Motherhood Penalty Larger for LowWage Women? A Comment on Quantile Regression.” American Sociological Review 79(2): 350-357.

Kossek, Ellen Ernst and Brian Distelberg. 2009. "Work and Family Employment Policy for a Transformed Labor Force: Current Trends and Themes." Pp. 3-49 in Work-Life Policies, 
edited by Ann C. Crouter and Alan Booth. Washington, D.C.: The Urban Institute Press. Landivar, Liana Christin. 2013. "Labor Force Participation Among Asian, Black, Hispanic, and White Mothers in 20 Occupations." Pp. 263-286 in Notions of Family: Intersectional Perspectives, edited by Marla H. Kohlman, Dana B. Krieg, and Bette J. Dickerson. UK: Emerald Group.

----. 2014. “Opting Out, Scaling Back, or Business-As-Usual: An Occupational Assessment of Women's Employment." Sociological Forum 29(1): 189-214.

-----. 2017. Mothers at Work: Who Opts Out? Boulder, CO: Lynne Rienner Publishers.

Laughlin, Lynda. 2011. "Maternity Leave and Employment Patterns: 2006-2008.” Current Population Reports P70-128. Washington, D.C.: U.S. Census Bureau.

Mathews, T. J. and Brady E. Hamilton. 2016. "Mean Age of Mothers is on the Rise: United States 2000-2014." NCHS Data Brief 232. Hyattsville, MD: National Center for Health Statistics.

Miller, Amalia R. 2011. “The Effects of Motherhood Timing on Career Path.” Journal of Population Economics 24(3): 1071-1100.

Noonan, Mary C., Mary E. Corcoran, and Paul N. Courant. 2003. "Pay Differences Among the Highly Trained: Cohort Differences in the Male-Female Earnings Gap in Lawyers' Salaries." National Poverty Center Working Paper Series \#03-1. Ann Arbor, MI: University of Michigan.

Ruggles, Steven, Katie Genadek, Ronald Goeken, Josiah Grover, and Matthew Sobek. 2015. Integrated Public Use Microdata Series: Version 6.0. Minneapolis: University of Minnesota.

Schieman, Scott, Melissa A. Milkie, and Paul Glavin. 2009. "When Work Interferes with Life: Work-Nonwork Interference and the Influence of Work-Related Demands and Resources." American Sociological Review 74(6): 966-988. 
Snijders, Tom. 2005. "Fixed and Random Effects." Pp. 664-665 in Encyclopedia of Statistics in Behavioral Science volume 2, edited by B.S. Everitt and D.C. Howell. Hoboken, NJ: Wiley.

Stone, Pamela. 2007. Opting Out? Why Women Really Quit Careers and Head Home. Berkeley: University of California Press.

Taniguchi, Hiromi. 1999. “The Timing of Childbearing and Women's Wages.” Journal of Marriage and Family 61(4): 1008-1019.

Waldfogel, Jane. 1998. "Understanding the 'Family Gap' in Pay for Women with Children." Journal of Economic Perspectives 12(1): 137-156.

Wilde, Elizabeth Ty, Lily Batchelder, and David T. Ellwood. 2010. “The Mommy Track Divides: The Impact of Childbearing on Wages of Women of Differing Skill Levels." Working Paper 16582. Cambridge, MA: National Bureau of Economic Research.

Yao, Lu, Julia Shu-Huah Wang, and Wen-Jui Han. 2017. “Women's Short-Term Employment Trajectories Following Birth: Patterns, Determinants, and Variations by Race/Ethnicity and Nativity." Demography 54: 93-118.

Yu, Wei-hsin and Janet Chen-Lan Kuo. 2017. "The Motherhood Wage Penalty by Work Conditions: How Do Occupational Characteristics Hinder or Empower Mothers?” American Sociological Review 82(4): 744-769. 


\section{Tables}

Table 1. Descriptive Statistics of Employed Women Ages 35-50 in 20 Select Occupations

\begin{tabular}{lrr}
\hline Variable & Mean & Standard Error \\
\hline $\begin{array}{l}\text { Individual characteristics } \\
\text { Age }\end{array}$ & 43.0 & 0.1 \\
First birth timing & & \\
$\quad$ Early (Less than 25) & 19.2 & 0.1 \\
$\quad$ Normative (25-27) & 13.9 & 0.1 \\
$\quad$ Delayed (28+) & 37.5 & 0.1 \\
$\quad$ No children & 29.4 & 0.1 \\
Birth in the past 12 months & 2.2 & 0.1 \\
Married & 66.8 & 0.1
\end{tabular}

Race

White, not Hispanic

68.7

0.1

Black

11.2

0.1

Asian

6.4

0.1

Other

5.8

0.1

Hispanic

11.7

0.1

Education

High school or lower

22.9

0.1

Some college

31.1

0.1

College degree or higher

46.0

0.1

Enrolled in school

6.7

0.1

Weeks worked

50-52 weeks

83.2

0.1

48-49 weeks

1.8

0.1

40-47 weeks

6.4

0.1

27-39 weeks

4.4

0.1

14-26 weeks

2.2

0.1

13 weeks or less

2.1

0.1

Hours worked

38.6

0.2

Earnings

50,645

76.7

Family income (earnings subtracted)

64,985

102.4

Occupational characteristics

Percent with autonomy

41.2

0.2

Specific vocational preparation (range 1-

6.0

0.1

9)

Percent licensing or certification

34.4

0.1

Source: U.S. Census Bureau, 2011-2015 American Community Survey Public Use Microdata Sample provided by the Integrated Public Use Microdata Series (IPUMS); U.S. Department of Labor O*NET online; and U.S. Department of Labor Occupational Outlook Handbook.

Notes: Per Census Bureau standards, standard errors are rounded to 0.01 if the standard error would otherwise appear to be 0 . 
Table 2. Occupational Characteristics of 20 Select Occupations

\begin{tabular}{|c|c|c|c|c|}
\hline Occupation & $\begin{array}{l}\text { Average } \\
\text { work hours } \\
\text { over } 40\end{array}$ & $\begin{array}{l}\text { High } \\
\text { degree of } \\
\text { autonomy }\end{array}$ & $\begin{array}{l}\text { Extensive } \\
\text { vocational } \\
\text { preparation }\end{array}$ & $\begin{array}{l}\text { Requires } \\
\text { licensing }\end{array}$ \\
\hline Managers & $\mathrm{X}$ & $\mathrm{X}$ & $\mathrm{X}$ & - \\
\hline Accountants and auditors ${ }^{1}$ & $\mathrm{X}$ & $\mathrm{X}$ & $\mathrm{X}$ & - \\
\hline Bookkeeping, accounting, and auditing clerks & - & - & $X$ & - \\
\hline Software developers & $\mathrm{X}$ & $\mathrm{X}$ & $X$ & - \\
\hline Lawyers & $\mathrm{X}$ & $\mathrm{X}$ & $\mathrm{X}$ & $\mathrm{X}$ \\
\hline Paralegals & - & $\mathrm{X}$ & $\mathrm{X}$ & $\mathrm{X}$ \\
\hline Elementary and middle school teachers & $\mathrm{X}$ & - & $\mathrm{X}$ & $\mathrm{X}$ \\
\hline Teacher assistants & - & - & $\mathrm{X}$ & - \\
\hline Physicians and surgeons & $\mathrm{X}$ & $\mathrm{X}$ & $\mathrm{X}$ & $\mathrm{X}$ \\
\hline Registered nurses & - & $\mathrm{X}$ & $\mathrm{X}$ & $\mathrm{X}$ \\
\hline Nursing, psychiatric, and home health aides & - & - & - & $\mathrm{X}$ \\
\hline Security guards & - & - & - & - \\
\hline Waiters and waitresses & - & - & - & - \\
\hline Maids and housekeeping cleaners & - & $\mathrm{X}$ & - & - \\
\hline Childcare workers & - & - & - & - \\
\hline Cashiers & - & - & - & - \\
\hline Retail salespersons & - & - & - & - \\
\hline Secretaries and administrative assistants & - & $\mathrm{X}$ & $X$ & - \\
\hline Assemblers & $\mathrm{X}$ & - & - & - \\
\hline Bus drivers & - & - & - & $\mathrm{X}$ \\
\hline
\end{tabular}

Sources: U.S. Census Bureau, 2011-2015 American Community Survey Public Use Microdata Sample provided by the Integrated Public Use Microdata Series (IPUMS); U.S. Department of Labor O*NET online; and U.S. Department of Labor Occupational Outlook Handbook.

Notes: ${ }^{1}$ Some accountants require licensing (e.g., Certified Public Accountants) but these are not identified separately in the Standard Occupational Classification. 
Table 3. Logged Earnings of Employed Women Ages 35-50: OLS Regression Model Estimates

\begin{tabular}{|c|c|c|c|c|c|}
\hline Variable & $\begin{array}{c}\text { Model } 1 \\
\text { Individual } \\
\text { characteristics }\end{array}$ & $\begin{array}{l}\text { Model } 2 \\
\text { Individual } \\
\text { characteristics } \\
\text { and autonomy }\end{array}$ & $\begin{array}{c}\text { Model } 3 \\
\text { Individual } \\
\text { characteristics } \\
\text { and SVP }\end{array}$ & $\begin{array}{c}\text { Model } 4 \\
\text { Individual } \\
\text { characteristics and } \\
\text { licensing }\end{array}$ & $\begin{array}{l}\text { Model } 5 \\
\text { Individual and } \\
\text { occupational } \\
\text { characteristics }\end{array}$ \\
\hline \multicolumn{6}{|l|}{$\begin{array}{l}\text { Dependent variable: natural log of } \\
\text { earnings }\end{array}$} \\
\hline Intercept & $9.95(0.08) * * *$ & $9.31(0.05) * * *$ & $9.07(0.18)^{* * *}$ & $9.92(0.08) * * *$ & $8.87(0.21)^{* * *}$ \\
\hline Individual characteristics & Included & Included & Included & Included & Included \\
\hline $\begin{array}{l}\text { First birth timing (ref. = no children) } \\
\text { Early ( } 24 \text { or earlier) } \\
\text { Normative }(25-27) \\
\text { Delayed (28 or later) }\end{array}$ & $\begin{array}{l}-0.07(0.10) \\
-0.06(0.08) \\
0.04(0.01)^{* * *}\end{array}$ & $\begin{array}{l}0.05(0.13) \\
-0.03(0.04) \\
-0.12(0.06)\end{array}$ & $\begin{array}{l}0.15(0.05)^{* *} \\
0.09(0.14) \\
-0.18(0.06)^{* *}\end{array}$ & $\begin{array}{l}-0.09(0.11) \\
-0.07(0.08) \\
0.03(0.01)^{* *}\end{array}$ & $\begin{array}{r}-0.06(0.07) \\
-0.05(0.04) \\
0.03(0.02)\end{array}$ \\
\hline $\begin{array}{l}\text { Occupational characteristics } \\
\text { Autonomy }(0-100,100=\mathrm{max}) \\
\text { Autonomy*Early } \\
\text { Autonomy*Normative } \\
\text { Autonomy*Delayed }\end{array}$ & & $\begin{array}{l}0.02(0.01) * * * \\
0.00(0.01) \\
0.00(0.01) \\
0.01(0.01) *\end{array}$ & & & $0.02(0.01) * * *$ \\
\hline $\begin{array}{l}\text { SVP }(1-9,9=\text { over } 10 \text { years }) \\
\text { SVP*Early } \\
\text { SVP*Normative } \\
\text { SVP*Delayed }\end{array}$ & & & $\begin{array}{l}0.16(0.03) * * * \\
-0.04(0.01) * * * \\
-0.03(0.03) \\
0.03(0.01) * * *\end{array}$ & & $0.05(0.01)^{* * *}$ \\
\hline $\begin{array}{l}\text { Licensing or certification required } \\
\text { License*Early } \\
\text { License*Normative } \\
\text { License*Delayed }\end{array}$ & & & & $\begin{array}{l}0.06(0.02)^{* *} \\
0.03(0.05) \\
0.03(0.02) \\
0.04(0.02)^{*}\end{array}$ & $0.26(0.05) * * *$ \\
\hline $\begin{array}{l}N \\
\mathrm{R}^{2}\end{array}$ & $\begin{array}{c}457,907 \\
0.58\end{array}$ & $\begin{array}{c}457,907 \\
0.62\end{array}$ & $\begin{array}{c}457,907 \\
0.61\end{array}$ & $\begin{array}{c}457,907 \\
0.58\end{array}$ & $\begin{array}{c}457,907 \\
0.64\end{array}$ \\
\hline
\end{tabular}

Source: U.S. Census Bureau, 2011-2015 American Community Survey Public Use Microdata Sample provided by the Integrated Public Use Microdata Series (IPUMS); U.S. Department of Labor O*NET online; and U.S. Department of Labor Occupational Outlook Handbook. Notes: $* \mathrm{p}<.05 * * \mathrm{p}<.01 * * * \mathrm{p}<.001$ (two-tailed tests). Standard errors are in parentheses. Per Census Bureau standards, standard errors are rounded to 0.01 if the standard error would otherwise appear to be 0. 
Table 4. Logged Earnings of Employed Women Ages 35-50: Multilevel Model Estimates of Individuals Clustered Within 20 Occupations

\begin{tabular}{|c|c|c|c|}
\hline Variable & $\begin{array}{c}\text { Model } 1 \\
\text { Intercept-only }\end{array}$ & $\begin{array}{c}\text { Model } 2 \\
\text { Random intercept }\end{array}$ & $\begin{array}{l}\text { Model } 3 \\
\text { Random intercept } \\
\text { and slopes for } \\
\text { timing of children }\end{array}$ \\
\hline \multicolumn{4}{|c|}{$\begin{array}{l}\text { Dependent variable: natural log of } \\
\text { earnings }\end{array}$} \\
\hline Intercept & $10.30(0.17)^{* * *}$ & $9.91(0.10)^{* * *}$ & $9.89(0.09)^{* * *}$ \\
\hline \multicolumn{4}{|l|}{ Individual characteristics } \\
\hline Age & & $0.01(0.01)^{* * *}$ & $0.01(0.01)^{* * *}$ \\
\hline \multicolumn{4}{|c|}{ First birth timing (ref. $=$ no children $)$} \\
\hline Early (24 or earlier) & & $-0.05(0.01)^{* * *}$ & $-0.04(0.01)^{* *}$ \\
\hline Normative (25-27) & & $-0.04(0.01)^{* * *}$ & $-0.03(0.01)^{*}$ \\
\hline Delayed (28 or later) & & $0.03(0.01)^{* * *}$ & $0.02(0.02)$ \\
\hline Birth in the past 12 months & & $0.08(0.01)^{* * *}$ & $0.07(0.01) * * *$ \\
\hline Married & & $-0.03(0.01)^{* * *}$ & $-0.03(0.01) * * *$ \\
\hline \multicolumn{4}{|c|}{ Race (ref. = White, not Hispanic) } \\
\hline Black & & $0.01(0.01)^{* * *}$ & $0.01(0.01)^{* * *}$ \\
\hline Asian & & $0.09(0.01) * * *$ & $0.09(0.01) * * *$ \\
\hline Other & & $0.01(0.01)^{* *}$ & $0.01(0.01)^{* *}$ \\
\hline Hispanic & & $0.01(0.01)$ & $0.01(0.01)$ \\
\hline \multicolumn{4}{|c|}{ Education (ref. = high school or lower) } \\
\hline Some college & & $0.09(0.01)^{* * *}$ & $0.09(0.01)^{* * *}$ \\
\hline College degree or higher & & $0.35(0.01)^{* * *}$ & $0.35(0.01) * * *$ \\
\hline Enrolled in school & & $-0.05(0.01)^{* * *}$ & $-0.05(0.01)^{* * *}$ \\
\hline \multicolumn{4}{|c|}{ Weeks worked (ref. $=50-52$ weeks) } \\
\hline 48-49 weeks & & $-0.13(0.01)^{* * *}$ & $-0.13(0.01) * * *$ \\
\hline 40-47 weeks & & $-0.20(0.01)^{* * *}$ & $-0.20(0.01)^{* * *}$ \\
\hline 27-39 weeks & & $-0.54(0.01)^{* * *}$ & $-0.53(0.01)^{* * *}$ \\
\hline 14-26 weeks & & $-1.11(0.01)^{* * *}$ & $-1.11(0.01)^{* * *}$ \\
\hline 13 weeks or less & & $-2.11(0.01)^{* * *}$ & $-2.11(0.01) * * *$ \\
\hline Hours worked & & $0.03(0.01)^{* * *}$ & $0.03(0.01) * * *$ \\
\hline Log of family income & & $0.05(0.01)^{* * *}$ & $0.05(0.01) * * *$ \\
\hline Occupation & & Included & Included \\
\hline$N$ & 459,451 & 457,907 & 457,907 \\
\hline Likelihood ratio chi-square & $1,083,371$ & 782,832 & 780,419 \\
\hline
\end{tabular}

Source: U.S. Census Bureau, 2011-2015 American Community Survey Public Use Microdata Sample provided by the Integrated Public Use Microdata Series (IPUMS).

Notes: * $\mathrm{p}<.05 * * \mathrm{p}<.01 * * * \mathrm{p}<.001$ (two-tailed tests). Standard errors are in parentheses. Per Census Bureau standards, standard errors are rounded to 0.01 if the standard error would otherwise appear to be 0 . 
Table 5. Occupation-Specific Effect of First Birth Timing Compared with Childless Women in the Same Occupation: Coefficients Derived from Multilevel Models ${ }^{1}$

\begin{tabular}{|c|c|}
\hline Variable & $\begin{array}{c}\text { Model } 3 \\
\text { Random intercept and slopes for } \\
\text { timing of children }\end{array}$ \\
\hline \multicolumn{2}{|l|}{ Dependent variable: natural log of earnings } \\
\hline Individual characteristics & Included (Table 4, Model 3) \\
\hline Managers & $0.33(0.09)^{* * *}$ \\
\hline Early & $-0.10(0.01)^{* * *}$ \\
\hline Delayed & $0.08(0.02) * * *$ \\
\hline Accountants and auditors & $0.26(0.09)^{* *}$ \\
\hline Early & $-0.04(0.02)^{*}$ \\
\hline Delayed & $0.03(0.02)$ \\
\hline Bookkeeping, accounting, and auditing clerks & $0.02(0.09)$ \\
\hline Early & $0.02(0.02)$ \\
\hline Delayed & $-0.05(0.02)^{*}$ \\
\hline Software developers & $0.61(0.10)^{* * *}$ \\
\hline Early & $-0.02(0.03)$ \\
\hline Delayed & $0.01(0.03)$ \\
\hline Lawyers & $0.68(0.09) * * *$ \\
\hline Early & $-0.12(0.03)^{* * *}$ \\
\hline Delayed & $0.16(0.02) * * *$ \\
\hline Paralegals & $0.24(0.09)^{* *}$ \\
\hline Early & $0.01(0.02)$ \\
\hline Delayed & $-0.01(0.03)$ \\
\hline Elementary and middle school teachers & $0.04(0.09)$ \\
\hline Early & $-0.08(0.02)^{* * *}$ \\
\hline Delayed & $-0.01(0.02)$ \\
\hline Teacher assistants & $-0.39(0.09)^{* * *}$ \\
\hline Early & $0.02(0.02)$ \\
\hline Delayed & $-0.14(0.02)^{* * *}$ \\
\hline Physicians and surgeons & $0.87(0.10)^{* * *}$ \\
\hline Early & $0.03(0.04)$ \\
\hline Delayed & $0.21(0.03)^{* * *}$ \\
\hline Registered nurses & $0.43(0.09)^{* * *}$ \\
\hline Early & $0.02(0.02)$ \\
\hline Delayed & $0.00(0.02)$ \\
\hline Nursing, psychiatric, and home health aides & $-0.31(0.09)^{* * *}$ \\
\hline Early & $0.07(0.02)^{* * *}$ \\
\hline Delayed & $0.03(0.02)$ \\
\hline Security guards & $-0.14(0.10)$ \\
\hline Early & $0.02(0.03)$ \\
\hline Delayed & $0.04(0.03)$ \\
\hline Waiters and waitresses & $-0.44(0.09)^{* * *}$ \\
\hline Early & $0.02(0.02)$ \\
\hline Delayed & $-0.01(0.02)$ \\
\hline Maids and housekeeping cleaners & $-0.50(0.09)^{* * *}$ \\
\hline Early & $0.09(0.02)^{* * *}$ \\
\hline Delayed & $0.02(0.02)$ \\
\hline
\end{tabular}




\begin{tabular}{lc} 
Childcare workers & $-0.52(0.09)^{* * * *}$ \\
Early & $0.01(0.02)$ \\
Delayed & $-0.19(0.03)^{* * *}$ \\
Cashiers & $-0.47(0.09)^{* * *}$ \\
Early & $0.04(0.02)^{*}$ \\
Delayed & $-0.02(0.02)$ \\
Retail salespersons & $-0.28(0.09)^{* *}$ \\
Early & $-0.03(0.02)$ \\
Delayed & $-0.05(0.02)^{*}$ \\
Secretaries and administrative assistants & $-0.02(0.09)$ \\
Early & $-0.01(0.01)$ \\
Delayed & $-0.07(0.02)^{* * *}$ \\
Assemblers & $-0.22(0.09)^{*}$ \\
Early & $0.03(0.02)$ \\
Delayed & $0.00(0.03)$ \\
Bus drivers & $-0.17(0.10)$ \\
Early & $0.05(0.02)^{*}$ \\
Delayed & $-0.02(0.03)$ \\
\hline
\end{tabular}

${ }^{1}$ Women with no children is the reference category. The estimated effect of normative childbearing is not displayed but available upon request.

Source: U.S. Census Bureau, 2011-2015 American Community Survey Public Use Microdata Sample provided by the Integrated Public Use Microdata Series (IPUMS). Notes: $* \mathrm{p}<.05 * * \mathrm{p}<.01 * * * \mathrm{p}<.001$ (two-tailed tests). Standard errors are in parentheses. Per Census Bureau standards, standard errors are rounded to 0.01 if the standard error would otherwise appear to be 0 . 


\section{Figures}

Figure 1. Unadjusted Earnings Penalty and Premium by Occupation and Mothers' Age at First Birth

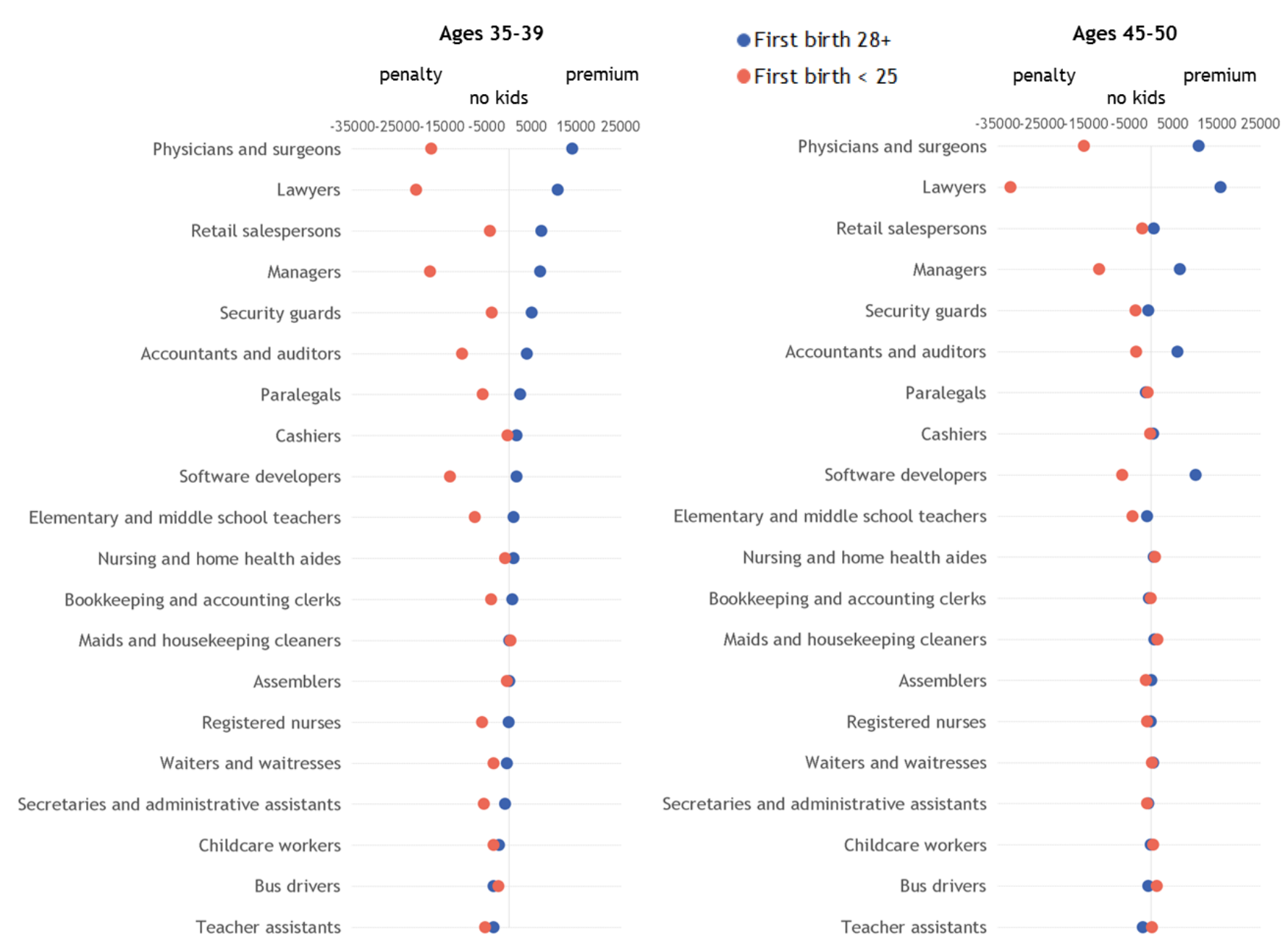

Source: U.S. Census Bureau, 2011-2015 American Community Survey Public Use Microdata Sample provided by the Integrated Public Use Microdata Series (IPUMS). 
Figure 2. The Association Between Occupational Characteristics and Earnings by Timing of First Birth: OLS Regression Results

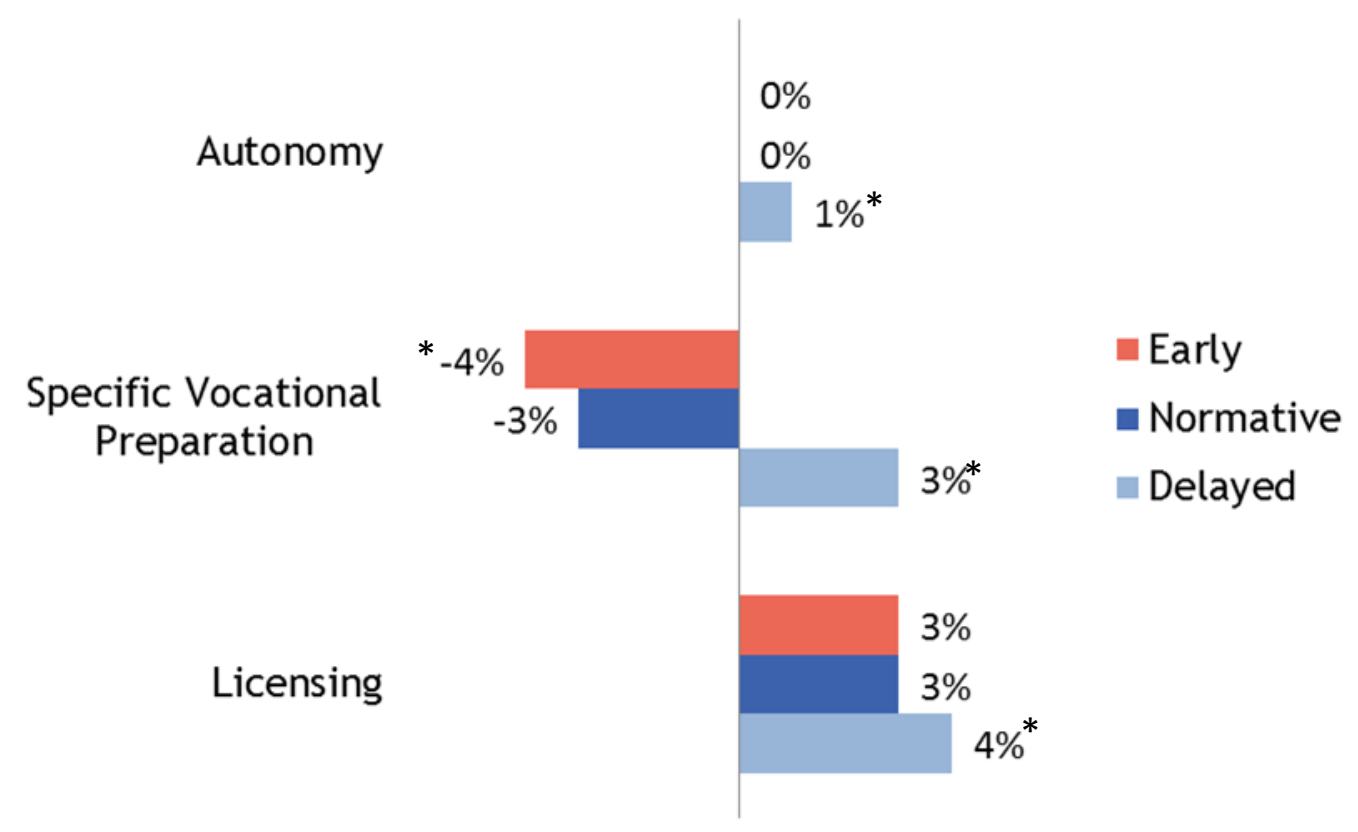

* = statistically significant at .05

Sources: U.S. Census Bureau, 2011-2015 American Community Survey Public Use Microdata Sample provided by the Integrated Public Use Microdata Series (IPUMS); U.S. Department of Labor O*NET online; and U.S. Department of Labor Occupational Outlook Handbook. 
Figure 3. The Association Between Earnings and Delayed First Birth by Occupation: Multilevel Model Results

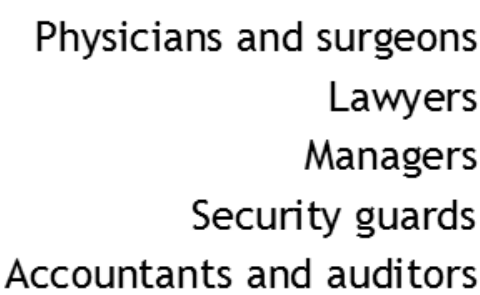

Nursing, psychiatric, and home health aides Maids and housekeeping cleaners Sof tware developers Registered nurses

Assemblers

Paralegals

Elementary and middle school teachers

Waiters and waitresses Cashiers

Bus drivers

Bookkeeping, accounting, and auditing clerks

Retail salespersons

Secretaries and administrative assistants

Teacher assistants

Childcare workers

\footnotetext{
* = statistically significant at .05
}

Source: U.S. Census Bureau, 2011-2015 American Community Survey Public Use Microdata Sample provided by the Integrated Public Use Microdata Series (IPUMS). 
Figure 4. The Association Between Earnings and Early First Birth by Occupation: Multilevel Model Results

Maids and housekeeping cleaners

Nursing, psychiatric, and home health aides

Bus drivers

Cashiers

Physicians and surgeons

Assemblers

Bookkeeping, accounting, and auditing clerks

Teacher assistants

Registered nurses

Security guards

Waiters and waitresses

Paralegals

Childcare workers

Secretaries and administrative assistants

Software developers

Retail salespersons

Accountants and auditors

Elementary and middle school teachers

Managers

Lawyers

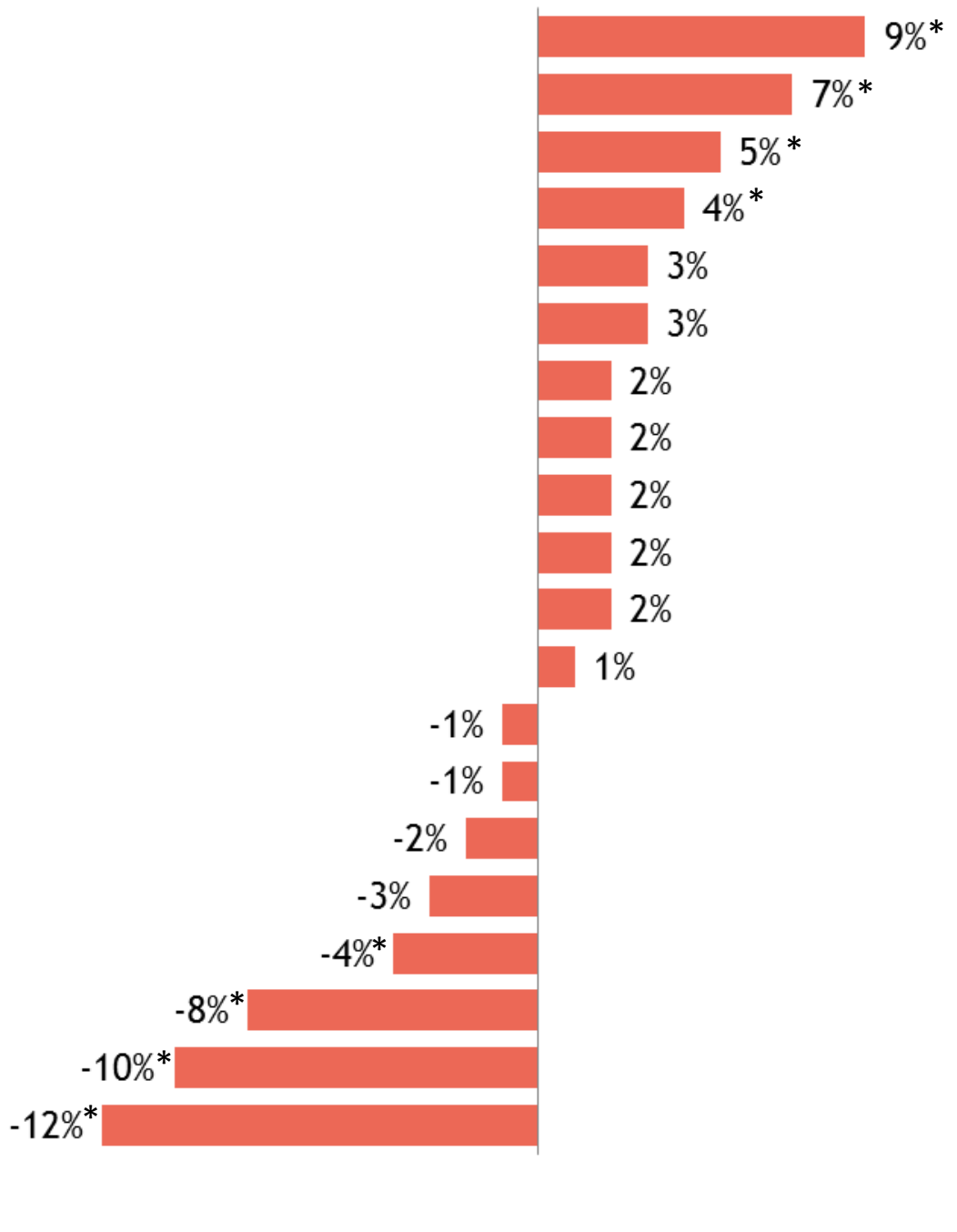

* = statistically significant at .05

Source: U.S. Census Bureau, 2011-2015 American Community Survey Public Use Microdata Sample provided by the Integrated Public Use Microdata Series (IPUMS). 
Figure 5. The Association Between Earnings and First Birth Timing Within Selected Industries: Multilevel Model Results

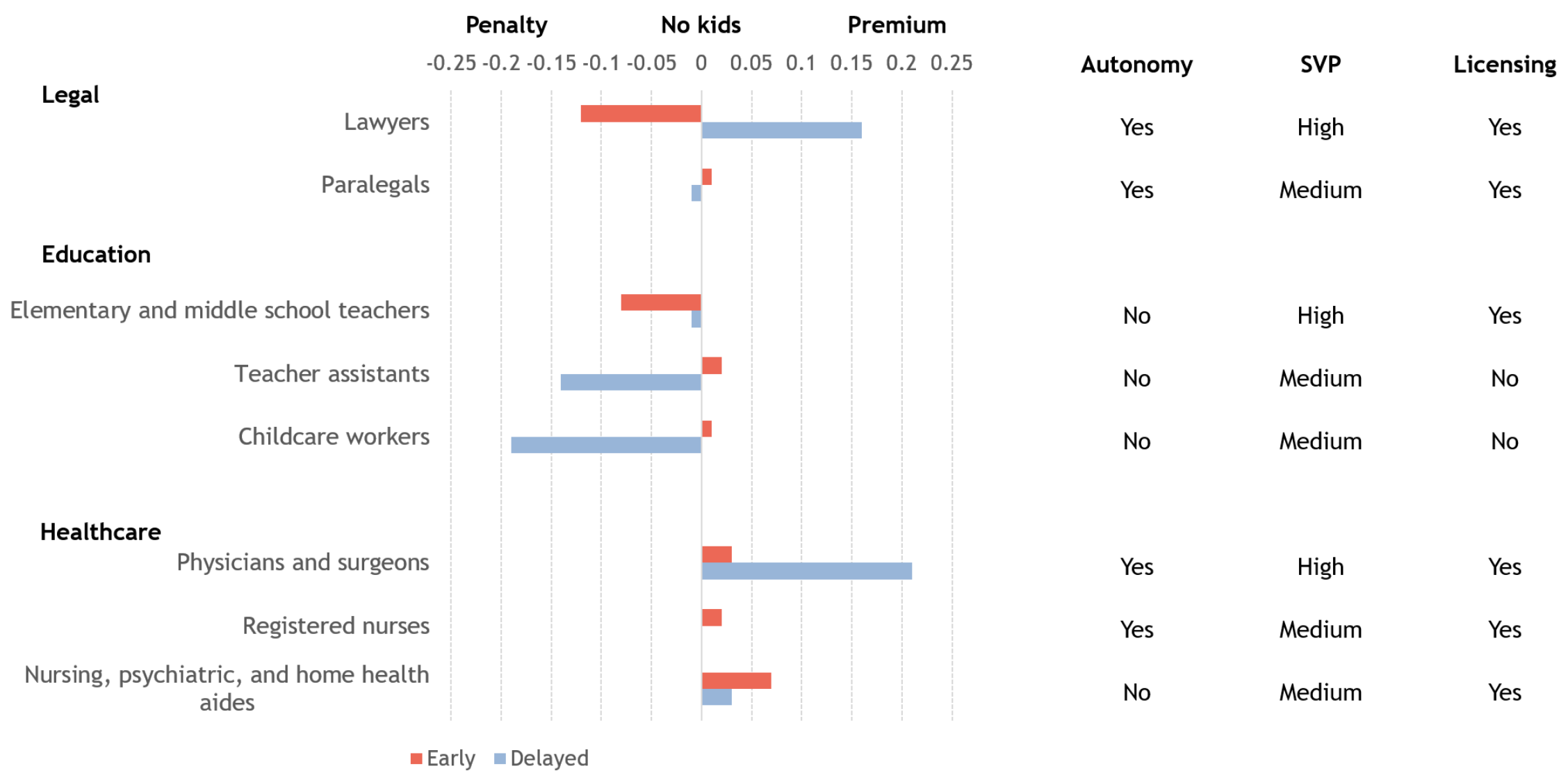

Sources: U.S. Census Bureau, 2011-2015 American Community Survey Public Use Microdata Sample provided by the Integrated Public Use Microdata Series (IPUMS); U.S. Department of Labor O*NET online; and U.S. Department of Labor Occupational Outlook Handbook. 